\title{
PENDIDIKAN MITIGASI BENCANA PADA KELUARGA DI DESA KEPUHARJO KECAMATAN CANGKRINGAN
}

\author{
Sakinah Anggun Estikawati, Nur Hidayah, dan Aris Martiana \\ Email : estikanggun@gmail.com
}

\begin{abstract}
Abstrak
Penelitian ini dilatarbelakangi adanya urgensi pelaksanaan pendidikan mitigasi bencana di Indonesia. Penelitian ini bertujuan untuk mengetahui bentuk dan dampak sosial budaya pendidikan mitigasi bencana pada keluarga di Desa Kepuharjo, Kecamatan Cangkringan. Penelitian ini menggunakan metode kualitatif deskriptif. Teknik pengumpulan data yang digunakan yakni observasi, wawancara dan dokumentasi. Teknik sampling yang digunakan dalam penelitian ini menggunakan purposive sampling. Validitas data dalam penelitian ini menggunakan teknik triangulasi sumber dengan model analisis data interaktif Miles dan Huberman. Hasil penelitian pendidikan mitigasi bencana pada keluarga di Desa Kepuharjo, Kecamatan Cangkringan bahwa pelaksanaan pendidikan mitigasi di keluarga cukup efektif untuk menumbhkan budaya tanggap bencana pada masyarakat sejak dini melalui keluarga. Materi yang disampaikan mencakup tindakan mengenali tanda alam sebelum erupsi, menunjukkan tempat dan jalur evakuasi, mempersiapkan dokumen penting, cara melindungi diri, mengenalkan daerah bahaya, hingga mengajak anak membersihkan lingkungan dari material vulkanik dengan memanfaatkan media koran serta obyek langsung dalam pembelajaran.
\end{abstract}

Kata Kunci : Pendidikan Mitigasi Bencana, Keluarga, Kepuharjo

\section{Abstract}

This background of this research is the urgency of implemention disaster mitigation education in Indonesia. This research aims to determine the form and the social impact of disaster mitigation education in family in Kepuharjo, Cagkringan. This research uses descriptive qualitative methods. The data collection techniques used are observations, interviews and documentation. The sampling techniques used purposive sampling. The validity of data in this study uses source triangulation techniques with interactive data analysis models of Miles and Huberman. The results of disaster mitigation educational research in family in Kepuharjo, Cangkringan that the implementation of mitigation education in family is effective enough to grow up the disaster response culture in society early through the family. The submitted materials include the Act of recognizing natural signs before the eruption, showing places and evacuation routes, preparing important documents, how to protect themselves, introducing danger areas, and inviting children to clean the environment of volcanic materials by utilizing newspaper media as well as direct object in the lesson

Keywords: Disaster Mitigation Education, Family, Kepuharjo

\section{Pendahuluan}

Indonesia memperoleh julukan sebagai Negara Jalur Ring Of Fire Pasifik yang menyebabkan Indonesia menjadi jalur pegunungan api aktif. Kondisi Indonesia yang kaya akan gunung berapi, menyebabkan kejadian bencana alam disebabkan oleh aktivitas gunung berapi. Salah satu gunung berapi yang aktif di Indonesia yaitu Gunung Merapi. Gunung Merapi terletak di Daerah Istimewa Yogyakarta dan Jawa Tengah. Telah terjadi puluhan kali letusan dari Gunung Merapi ini dimulai dari sekitar 3.000 tahun yang lalu. Pingit (2019) menyebutkan bahwa tercatat pada tahun 1768 hingga tahun 2019 telah terjadi ribuan kali letusan dan banyak menimbulkan kerugian materil maupun non materil. 
Keberadaan kawasan padat penduduk yang dijumpai di Lereng Gunung Merapi semakin menimbulkan banyaknya korban jiwa apabila terjadi erupsi. Anik (2010) mengemukakan terdapat 34 desa di Lereng Gunung Merapi yang harus dikosongkan semasa periode letusan pada tahun 2010 karena wilayah tersebut memiliki risiko dari erupsi. Salah satu desa yang terletak di Lereng Gunung Merapi yaitu Desa Kepuharjo. Letak Desa Kepuharjo yang rawan terhadap risiko dari erupsi Merapi dikarenakan dilalui oleh dua sungai yang berhulu di Gunung Merapi yaitu Sungai Gendol dan Sungai Opak (Syamsul, 2015: 35-37). Akbar (2018) mengemukakan bahwa terdapat 362 jiwa yang terdiri atas 35 balita, 12 lansia, 39 anak-anak, 41 remaja, dan 235 dewasa, mengungsi karena trauma dengan letusan Merapi 2010 lalu yang memakan banyak korban jiwa. Hal tersebut menjadikan pendidikan mitigasi bencana penting untuk dilaksanakan.

Murdyastomo (2011) menyebutkan bahwa dengan diadakannya pendidikan mitigasi bencana diharapkan masyarakat dapat memahami ancaman yang ditimbulkan dari bencana. Pendidikan mitigasi bencana yang terjadi di Desa Kepuharjo terlaksana melalui berbagai sektor, baik itu melalui pendidikan formal, informal, maupun non formal. Terkhusus pada pelaksanaan pendidikan mitigasi pada sektor informal, pendidikan mitigasi terlaksana di keluarga-keluarga Desa Kepuharjo. Berdasarkan berbagai pengalaman yang dimiliki masyarakat setempat mereka memiliki cara khusus untuk mengajarkan anak untuk mengenali kondisi alam yang mereka tinggali. Orang tua di sana sebagian besar melibatkan anak secara langsung untuk mengamati kondisi Merapi. Pelaksanaan pendidikan mitigasi bencana yang dilaksanakan di Desa Kepuharjo ini tidak banyak mengalami kendala, terutama pada pendidikan mitigasi pada keluarga. Keterampilan pendidik dalam memberikan pengetahuan akan mitigasi bencana dirasa masih belum maksimal. Nurjanah (2013: 54) mengemukakan bahwa mitigasi bencana merupakan upaya yang dilakukan guna mengurangi risiko yang disebabkan oleh bencana. Noor (2014) mengemukakan bahwa terdapat dua jenis mitigasi bencana, yaitu mitigasi struktural dan mitigasi non struktural. Kusumasari (2014) menyebutkan pelaksanaan mitigasi bencana dilakukan secara terencana melalui beberapa upaya dan pendekatan. Terdapat empat pendekatan dalam mitigasi bencana antara lain pendekatan teknis, pendekatan manusia, pendekatan administratif, dan pendekatan kultural.

Berdasarkan Permendikbud Nomor 33 Tahun 2019 tentang penyelenggaraan program satuan pendidikan aman bencana merupakan peraturan yang dibentuk oleh menteri pendidikan dan kebudayaan yang bertujuan untuk memberikan perlindungan dan keselamatan pada peserta didik, pendidikan, dan tenaga kependidikan dari risiko yang ditimbulkan. Materi yang 
diberikan dalam pendidikan mitigasi bencana yakni menjelaskan langkahlangkah yang perlu untuk dilakukan untuk mitigasi bencana. Pada hal ini, akan dibagi menjadi tiga langkah diantaranya sebelum terjadinya gunung meletus, saat terjadinya gunung meletus, dan setelah terjadinya gunung meletus.

Menurut Septikasari (2018: 52-54), terdapat tiga strategi dalam pelaksanaan pendidikan mitigasi bencana antara lain penggunaan media surat kabar dalam pembelajaran; penggunaan media obyek nyata dengan membawa anak ke obyek secara langsung; dan penggunaan media gambar dan LKS acak kata. Siti Irene (2010: 40-41) mengemukakan dalam jurnalnya yang berjudul "Peran Sekolah Dalam Pembelajaran Mitigasi Bencana" bahwa pembelajaran outbond dan pemanfaatan kearifan lokal daerah setempat merupakan salah satu model pembelajaran yang tepat digunakan dalam penerapan pendidikan mitigasi bencana.

Keluarga didefinisikan sebagai sekumpulan orang yang tinggal dalam satu rumah yang masih mempunyai hubungan kekerabatan atau hubungan darah karena perkawinan, kelahiran, adopsi dan lain sebagainya. Vebriarto (dalam Khairudin, 2008: 4) menyebutkan bahwa keluarga merupakan kelompok primer yang di dalamnya terdapat ciri kooperatif, adanya hubungan intim, face to face, serta masing-masing anggota memberlakukan anggota lain bukan untuk mencapai tujuan. Berdasarkan Friedman (dalam Fauziah,
2016: 7-8), keluarga memiliki fungsi pokok yang tidak dapat digantikan perannya oleh pihak lain. Fungsi pokok yang dimiliki oleh keluarga, seperti fungsi biologik, fungsi afeksi, fungsi sosialisasi, fungsi proteksi, fungsi edukasi, fungsi religius, fungsi rekreasi, dan fungsi ekonomis.

Vander (dalam Jamal Syarif, 2007) mengemukakan bahwa sosialisasi yaitu proses interaksi sosial yang menjadikan individu mengenal cara untuk berpikir, berperasaan, serta bertingkah laku sehingga memiliki peran dalam kehidupan bermasyarakat. Berger (dalam Karmin, 2015: 8) mengemukakan bahwa sosialisasi terjadi dalam dua fase, yaitu sosialisasi primer dan sosialisasi sekunder. Berns (dalam Astutik, 2017: 65) menyebutkan bahwa terdapat lima agen sosialisasi utama yaitu keluarga, kelompok bermain, media massa, lingkungan kerja, dan lembaga pendidikan sekolah. Waters (dalam Jamal Syarif, 2007: 6-9) mengemukakan bahwa proses sosialisasi terjadi melalui tiga tahapan diantaranya peniruan: generalisasi; dan penguatan.

\section{Metode}

Desain penelitian yang digunakan pada penelitian ini menggunakan pendekatan kualitatif deskriptif. Penelitian kualitatif ini bertujuan untuk memahami fenomena mengenai pendidikan mitigasi bencana pada keluarga yang dilaksanakan di Desa Kepuharjo Kecamatan Cangkringan. Lokasi yang digunakan dalam penelitian ini yaitu di Desa 
Kepuharjo, Kecamatan Cangkringan, Kabupaten Sleman, Daerah Istimewa Yogyakarta. Penelitian ini membutuhkan waktu lebih kurang tiga bulan, terhitung dari bulan Desember 2019 hingga Februari 2020. Subyek penelitian pada penelitian ini yaitu keluarga di Desa Kepuharjo yang menerapkan pendidikan mitigasi bencana pada keluarganya.Populasi dalam penelitian ini adalah warga di Desa Kepuharjo, Kecamatan Cangkringan. Pada penelitian ini pemilihan informan menggunakan teknik purposive sampling. Sumber data pada penelitian ini menggunakan sumber data primer dan sekunder. sumber data primer pada penelitian ini yaitu melalui wawancara dan observasi. Sedangkan untuk sumber data sekunder yang digunakan dalam penelitian ini yaitu dokumentasi dan studi pustaka yang dapat mendukung penelitian ini. Teknik dan instrumen penelitian yang digunakan yaitu menggunakan wawancara, observasi, dan dokumenasi.

Penelitian ini menggunakan teknik validitas data berupa triangulasi sumber. Pada penelitian ini, triangulasi sumber dilakukan dengan cara menanyakan ulang mengenai data yang telah diperoleh melalui wawancara dengan informan. Sedangkan penelitian ini menggunakan model analisis data interaktif menurut Miles dan Huberman. Model analisis data ini memiliki 3 tahapan, yaitu tahap pertama kondensasi data (data condensation), tahap kedua penyajian data (data display), dan tahap ketiga penarikan kesimpulan

serta verifikasi data (conclusion and verification).

\section{Hasil dan Pembahasan}

\section{Bentuk Pendidikan Mitigasi Bencana pada Keluarga di Desa Kepuharjo Kecamatan \\ Cangkringan}

a. Materi Pendidikan Mitigasi Bencana

Materi yang diberikan dalam pelaksanaan pendidikan mitigasi bencana pada keluarga meliputi pemahaman terkat tindakan yang perlu dilakukan sebelum, saat, dan sesudah terjadinya erupsi. berikut materi yang diberikan dalam pelaksanaan pendidikan mitigasi bencana pada eluarga di Desa Kepuharjo Kecamatan Cangkringan.

1) Sebelum terjadinya bencana

Pertama yaitu orang
tua mengenalkan ciri-ciri
kondisi alam sebelum terjadi
erupsi. Orang tua di
Kepuharjo memberikan
materi mengenai cara
mengamati ciri-ciri kondisi
sekitar melalui kenaikan suhu
udara, masuknya hewan-
hewan ke pemukiman,
sumber mata air yang
mengering, dan tanaman
yang mulai layu. Anak harus
dibiasakan diri untuk
Kecamatan Cangkringan I Sakinah Anggun Estikawati, Nur Hidayah, dan Aris Martiana 
memahami kondisi sekitar agar dapat tertanam sikap peduli dan waspada. Selama ini, orang tua memberikan pemahaman kepada anak mengenai tanda-tanda alam yang muncul sebelum terjadi erupsi yaitu melalui pengamatan langsung..

Kedua yaitu orang tua mengenalkan tingkatan aktivitas status Merapi. Orang tua memberikan pengetahuan kepada anak terkait dengan tingkatan status yang dimiliki oleh Merapi sembari menggunakan media bantu dari internet, terutama BMKG ataupun koran. Materi yang diberikan orang tua kepada anak terkait dengan tingkatan status Merapi bertujuan agar anak lebih memahami kondisi Merapi, sehingga mereka tidak akan gegabah dalam menentukan sikap apabila Merapi mengalami sesuatu.

Ketiga yaitu orang tua mengenalkan tempat dan jalur evakuasi. Tindakan ini merupakan upaya untuk mempersiapkan diri apabila sewaktu-waktu Merapi mengalami erupsi dan tidak lagi aman apabila masyarakat masih berdiam diri di rumah. Memberitahukan titik kumpul, lokasi evakuasi, dan jalur evakuasi dilakukan sebelum terjadinya erupsi agar pada saat terjadinya erupsi dan terpaksa harus melakukan evakuasi masyarakat sudah mengetahui dimana titik kumpul yang aman, jalur mana saja yang harus ditempuh, dan lokasi tujuan untuk evakuasi.

Keempat yaitu orang tua mengajak anak untuk mempersiapkan dokumen penting. Berdasarkan buku panduan tanggap bencana, yang tergolong dalam dokumen-dokumen penting yang perlu dipersiapkan sebelum terjadinya bencana meliputi kartu keluarga, akte kelahiran, copy identitas diri, ijazah, sertifikat-sertifikat, surat nikah, buku rekening bank, dan surat penting lainnya. Seluruh dokumendokumen tersebut perlu memperoleh perhatian khusus agar tidak tertinggal dan hilang saat terjadinya erupsi. Orang tua membiasakan melibatkan anak dalam mempersiapkan dokumen-dokumen penting sehingga anak mulai memahami dan menyadari bahwa ia perlu untuk 
melakukan tindakan tersebut agar dokumen dapat selamat.

2) Saat terjadinya bencana

$$
\begin{aligned}
& \text { Pertama yaitu orang } \\
& \text { tua memberitahu cara } \\
& \text { melindungi diri dari material } \\
& \text { vulkanik. Pemberian materi } \\
& \text { yang diberikan saat } \\
& \text { pelaksanaan pendidikan } \\
& \text { mitigasi pada keluarga di } \\
& \text { Keluarga berlangsung } \\
& \text { dengan orang tua } \\
& \text { memberikan himbauan } \\
& \text { kepada anak untuk selalu } \\
& \text { menjaga hidung, mulut, dan } \\
& \text { mata agar tidak terkena } \\
& \text { langsung berbagai material } \\
& \text { vulkanik yang } \\
& \text { membahayakan. Orang tua } \\
& \text { memberikan contoh pada } \\
& \text { anak untuk menggunakan } \\
& \text { asker dan kacamata agar } \\
& \text { mereka dapat terlindung dari } \\
& \text { material vulkanik akibat } \\
& \text { erupsi. Selama ini } \\
& \text { pemahaman yang dimiliki } \\
& \text { oleh masyarakat cukup baik } \\
& \text { terkait dengan cara } \\
& \text { melindungi diri dari material } \\
& \text { vulkanik Merapi. } \\
& \text { Kedua yaitu orang tua } \\
& \text { mengenalkan daerah bahaya } \\
& \text { saat terjadi erupsi. } \\
& \text { Berdasarkan Keputusan } \\
& \text { Kabadiklat Kemhan tahun } \\
& \text { 2016, masyarakat perlu } \\
& \text { menghindari daerah rawan }
\end{aligned}
$$

bencana saat terjadinya erupsi yakni daerah lereng gunung, lembah, dan daerah aliran lahar. Selama ini orang tua mengajarkan kepada anak terkait materi daerah yang harus dihindari saat terjadi erupsi dengan cara mengajak langsung anak ke daerah yang dituju. Sembari mendatangi langsung lokasi yang dituju, orang tua memberikan berbagai penjelasan terkait bagaimana daerah tersebut berbahaya dan dampaknya apabila mereka mendatangi daerah tersebut saat terjadi erupsi.

3) Setelah terjadinya bencana

Pertama yaitu orang tua memberitahu daerah yang masih terdampak dari adanya erupsi. Meskipun erupsi telah berakhir dan kondisi sudah mulai aman, akan tetapi masyarakat harus tetap memiliki sikap antisipasi apabila sewaktu-waktu akan terjadi erupsi susulan maupun bahaya dari sisa dari erupsi sebelumnya. Orang tua memberikan pemahaman ke anak dengan mengajak langsung ke lokasi kejadian sembari diberikan penjelasan. Selama ini orang tua memperoleh informasi 


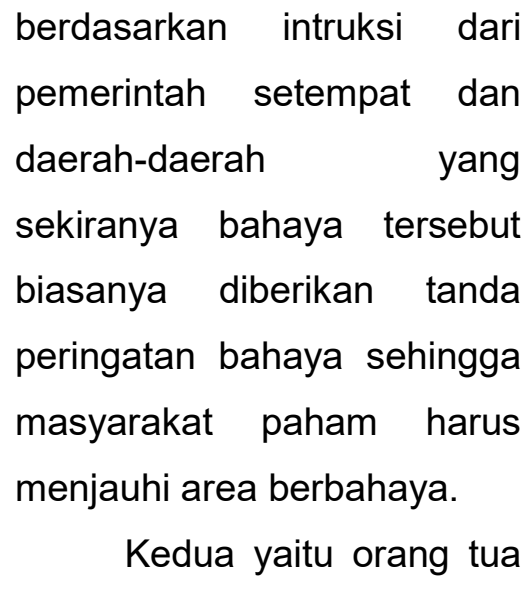
memberitahukan cara membersihkan lingkungan tempat tinggal dari material vulkanik. Pemberian materi yang dilakukan orang tua kepada anak mengenai cara membersihkan lingkungan sekitar dari material vulkanik dalam pembelajaran mitigasi pada keluarga di Kepuharjo dilakukan dengan cara orang tua selalu melibatkan anak dalam kegiatan bersih-bersih. Orang tua akan melakukan pembagian tugas dengan anak, agar anak terlibat aktif dalam prses bersih-bersih material ini. Melalui cara seperti ini anak akan terbiasa dengan kondisi setelah terjadinya erupsi sehingga muncul kesadaran untuk beres-beres rumah agar dapat tinggal di lingkungan yang sehat dan lebih nyaman. Orang tua di Kepuharjo dalam memberikan materi pembelajaran pendidikan mitigasi pada keluarga di Desa Kepuharjo berdasarkan sosialisasi yang mereka peroleh dari pemerintah setempat, lembaga kebencanaan, hingga kearifan lokal yang terdapat di Kepuharjo. Oleh karena itu, materi yang diberikan oleh orang tua di sana dapat diuji kebenarannya dan tidak menimbulkan penyesatan pengetahuan pada anak.

b. Media Pembelajaran Pendidikan Mitigasi Bencana

Pelaksanaan pendidikan mitigasi perlu adanya media pembelajaran untuk menyampaikan berbagai materi yang akan diberikan orang tua kepada anak. Berikut hasil temuan penelitian mengenai media pembelajaran yang digunakan orang tua dalam pelaksanaan pendidikan mitigasi bencana pada keluarga di Desa Kepuharjo.

Pertama yaitu penggunaan media surat kabar atau koran. Banyak sekali informasi terkait kebencanaan yang dibagikan melalui media surat kabar sebagai sarana pendukung pelaksanaan pendidikan mitigasi. Orang tua tidak hanya menggunakan satu sumber koran yang digunakan sebagai media 
pembelajaran. Terdapat

beberapa sumber koran yang digunakan seperti kompas, CNN, kedaulatan rakyat, hingga radar untuk menjadi sumber acuan menggali informasi terkait kebencanaan. Melihat fenomena yang terjadi pada keluarga di Desa Kepuharjo dalam melaksanakan pendidikan mitigasi bencana, terdapat keterlibatan agen sosialisasi media massa. Pengaruh keberadaan media massa berupa surat kabar memiliki andil pada proses sosialisasi individu dalam pemahaman akan mitigasi bencana. Informasi yang terdapat pada surat kabar terkait kondisi kebencanaan dapat meningkatkan kewaspadaan yang dimiliki para pembaca.

Media pembelajaran yang digunakan oleh orang tua dalam melaksanakan pendidikan mitigasi bencana pada keluarga selaras dengan metode pembelajaran dengan pemanfaatan surat kabar dalam pembelajaran mitigasi yang diungkapkan oleh Septikasari (2018: 52-54). Berdasarkan penelitian yang dilakukan Septikasari menunjukkan bahwa pemanfaatan media surat kabar atau koran dapat melatih anak dalam berpikir kritis. Berbagai informasi terkait kebencanaan yang terdapat dalam koran dapat menambah wawasan pada anak.

Kedua yaitu penggunaan media obyek nyata dengan mengajak anak ke lokasi secara langsung. Orang tua mengajak anak untuk mengamati langsung kondisi lingkungan sekitar yang terjadi. Media yang digunakan ini dirasa efektif karena anak tidak hanya diberikan pemahaman secara materi yang monoton saja, akan tetapi mereka dapat melihat secara langsung kondisi yang terjadi.

Media pembelajaran yang digunakan oleh orang tua dalam melaksanakan pendidikan mitigasi bencana pada keluarga selaras dengan metode pembelajaran dengan pemanfaatan obyek nyata dalam pembelajaran mitigasi yang diungkapkan oleh Septikasari (2018: 52-54). Septikasari menyebutkan mengajak anak ke obyek nyata akan menjadikan anak mudah memahami apa yang diajarkan apabila ia diajak terjun langsung ke obyeknya. Mengajak anak ke lokasi langsung akan dapat memudahkan anak untuk mengeksplore dan berimajinasi dengan kondisi yang sesungguhnya. 
c. Faktor Pendorong dan Faktor Penghambat Pendidikan Mitigasi Bencana

1) Faktor pendorong

Pertama yaitu adanya kesadaran dalam diri masyarakat karena tinggal di daerah rawan bencana. Melihat kondisi lingkungan sekitar yang ditinggali menjadikan mereka sadar akan dampak bahaya yang mengancam. Sehingga mereka membutuhkan persiapan dalam menghadapi erupsi Merapi.

Kedua yaitu jalinan komunikasi antar anggota keluarga yang baik. Pada kesehariannya, anak lebih banyak menghabiskan waktu bersama keluarga. Melihat kesempatan tersebut dapat dimanfaatkan oleh kedua orang tua dalam penyampaian pemahaman akan mitigasi bencana. Kedekatan yang intens antara anak dan kedua orang tua akan membangun kenyamanan, sehingga proses pendidikan yang dilaksanakan di sana akan berjalan dengan efektif.

Ketiga yaitu adanya motivasi untuk selamat. Adanya dorongan untuk menyelamatkan diri dari bahaya, maka masyarakat mulai mempelajari bagaimana cara untuk menyikapi sebelum, saat, dan sesudah terjadinya bencana. Melalui proses pemahaman yang dilakukan melalui pendidikan mitigasi bencana, maka tingkat kewaspadaan akan bahaya yang ditimbulkan dari erupsi Merapi akan meningkat.

Keempat yaitu adanya program kegiatan yang diselenggarakan oleh pemerintah desa setempat. Adanya kerjasama antara pemerintah desa setempat dengan lembaga kebencanaan maupun komunitas kebencanaan guna menambah kapasitas pengetahuan masyarakat. IImu yang diperoleh melalui kegiatan-kegiatan yang diselenggarakan oleh pemerintah dapat membantu keluarga-keluarga di Desa Kepuharjo dalam pelaksanaan pendidikan mitigasi bencana.

Kelima yaitu adanya penerapan pendidikan mitigasi bencana di sekolah. Sekolah-sekolah yang ada di Desa Kepuharjo merupakan 
sekolah siaga bencana, sehingga anak telah dibekali mengenai kebencanaan di sana. Hal ini mempermudah pihak keluarga di rumah dalam pelaksanaan pendidikan mitigasi karena anak tidak hanya memperoleh pemahaman dari keluarga saja, akan tetapi juga di sekolah.

Keenam yaitu adanya pengaruh dari lingkungan kerja. Lingkungan tempat kerja secara tidak langsung dapat mempengaruhi dalam pelaksanaan pendidikan mitigasi bencana dalam keluarga. Dapat diketahui apabila bekerja di lembaga kebencanaan tentu akan memperoleh banyak sekali pengalaman dalam penanganan bencana. Selain itu, berbagai pelatihan dan materi telah diperoleh sebagai bekal untuk menjalankan tugas sebagai tim kebencanaan.

2) Faktor penghambat

$$
\text { Pertama yaitu adanya }
$$
trauma dan tingkat pemahaman yang dimiliki oleh anak. Dampak yang ditimbulkan dari adanya erupsi Merapi menyebabkan trauma bagi anak maupun

masyarakat lainnya. Hal ini terjadi karena adanya ketidaksiapan dan rasa terkejut individu dalam menghadapi erupsi yang datang tiba-tiba.

Kedua yaitu ketidakstabilan sikap yang dimiliki oleh anak. Ketidakstabilan sikap yang dimiliki oleh anak menjadi penghambat orang tua dalam pelaksanaan pendidikan mitigasi pada keluarga. Sehingga pada saat diberikan pemahaman akan mitigasi menjadikan orang tua kurang dapat memberikan pembelajaran secara maksimal.

$$
\begin{aligned}
& \text { Ketiga yaitu kondisi } \\
& \text { yang dimiliki anggota } \\
& \text { keluarga. Keluarga terdiri dari } \\
& \text { orang tua dan anak, bahkan } \\
& \text { ada pula keluarga yang } \\
& \text { tinggal bersama dengan } \\
& \text { anggota keluarga lainnya, } \\
& \text { misalnya nenek. Individu } \\
& \text { yang sudah jompo ataupun } \\
& \text { berumur tentu akan sulit } \\
& \text { sekali untuk menerima } \\
& \text { informasi yang diberikan. } \\
& \text { Orang yang sudah tua } \\
& \text { cenderung memiliki } \\
& \text { pemikiran yang kolot dan } \\
& \text { enggan dengan mudah } \\
& \text { menerima perubahan. }
\end{aligned}
$$

Pendidikan Mitigasi Bencana pada Keluarga di Desa Kepuharjo Kecamatan Cangkringan | Sakinah Anggun Estikawati, Nur Hidayah, dan Aris Martiana 
Sehingga mereka sulit untuk menerima informasi yang diberikan.

Keempat yaitu minimnya materi mitigasi bencana yang diberikan orang tua. Tidak semua masyarakat memiliki pengetahuan yang baik akan mitigasi bencana. $\mathrm{Hal}$ tersebut karena mereka memang bukan ahli dalam bidang kebencanaan. Pemahaman yang dimiliki hanyalah pemahaman dasar mitigasi bencana.

2. Dampak Sosial dan Budaya Pendidikan Mitigasi Bencana pada Keluarga di Desa Kepuharjo Kecamatan Cangkringan

a. Dampak Positif

$$
\text { Pertama yaitu }
$$
meningkatkan kewaspadaan masyarakat dalam menghadapi erupsi Gunung Merapi. Melalui pemahaman akan mitigasi bencana yang diberikan orang tua menjadikan anak lebih meningkatkan sikap waspada mereka, sehingga apabila terjadi erupsi mereka sudah siap siaga. Masyarakat menjadi lebih memahami bagaimana karakter yang dimiliki oleh Merapi dan bagaimana sikap yang perlu

dilakukan untuk menghadapi setiap kondisi yang terjadi.

Kedua yaitu meningkatkan pemahaman mitigasi bencana yang dimiliki masyarakat. Pemahaman mitigasi bencana yang dimiliki oleh anggota keluarga menjadikan mereka dapat bertindak mandiri. Sehingga saat terjadi erupsi dan tidak terdapat kepala keluarga (orang yang mengajarkan mitigasi bencana), anggota keluarga yang lainnya dapat menentukan sikap yang harus dilakukan.

Ketiga yaitu meningkatkan solidaritas sosial yang dimiliki masyarakat. Upaya mitigasi bencana tidak dapat dilakukan seorang diri kan tetapi melibatkan beberapa orang di dalamnya agar proses mitigasi dapat berhasil. Pada setiap tahapan mitigasi bencana yang dilaksanakan tentu memiliki mekanismenya masingmasing, sehingga memerlukan kerja sama dengan orang lain. Prinsip yang dipegang dalam mitigasi bencana pada masyarakat yakni apabila ingin selamat harus menjaga keselamatan secara bersamasama.

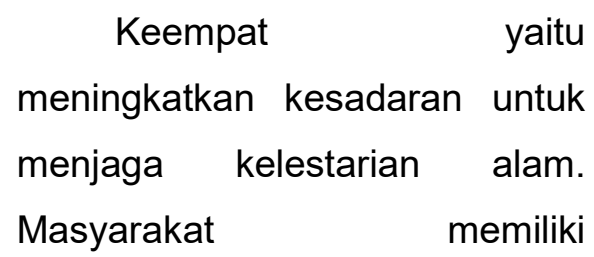


kepercayaan bahwa adanya keselarasan antara alam dengan keberadaan manusia. Kekayaan alam yang dimiliki menjadikan masyarakat setempat dalam memenuhi kebutuhan hidup dan bertahan hidup bergantung pada kondisi alam. Melalui kekayaan sumber daya alam yang dimiliki dan dimanfaatkan untuk keberlangsungan hidup, masyarakat harus tetap menjaga kelestarian alam.

b. Dampak Negatif

Dampak negatif dari pelaksanaan pendidikan mitigasi bencana pada keluarga menjadikan timbulnya penyalahgunaan pengetahuan mitigasi yang dimiliki anak. Seringnya anak diberikan pemahaman akan mitigasi bencana oleh orang tua tentu akan menambahkan pemahaman dan kesadaran mereka akan mitigasi. Akan tetapi, melalui pemahaman yang baru mereka miliki tersebut sering disalahgunakan. Anak merasa dengan pemahaman yang telah mereka terima tersebut menjadikan mereka sudah ahli dalam hal mitigasi. Sehingga mereka tidak heran untuk menolong orang lain dalam situasi berbahaya tanpa mempertimbangkan risiko yang akan ditimbulkan.

\section{Simpulan}

Bentuk pendidikan mitigasi bencana pada keluarga di Desa Kepuharjo terlaksana cukup baik dan efektif. Materi yang disampaikan meliputi mengenalkan ciri kondisi alam sebelum erupsi, mengenalkan tingkatan aktivitas status Merapi, mengenalkan tempat dan jalur untuk melakukan evakuasi, mempersiapkan dokumen penting, cara melindungi diri dari material vulkanik, mengenalkan daerah bahaya saat erupsi, mengenalkan cara membersihkan lingkungan tempat tinggal dari material vulkanik. Media pembelajaran yang digunakan orang tua untuk mengajarkan pendidikan mitigasi bencana pada keluarga di Desa Kepuharjo dengan menggunakan media surat kabar berupa koran dan media obyek nyata dengan membawa anak ke obyek secara langsung.

Pendidikan mitigasi bencana pada keluarga di Desa Kepuharjo dalam pelaksanaannya tentu menemukan berbagai faktor pendukung dan penghambat. Faktor pendukung yang ditemukan dalam pelaksanaan pendidikan mitigasi bencana di Kepuharjo diantara adanya kesadaran dalam diri masyarakat karena tinggal di daerah rawan bencana; jalinan komunikasi antar anggota keluarga yang baik; adanya motivasi untuk selamat; adanya program kegiatan yang 
diselenggarakan oleh pemerintah desa setempat; penerapan pendidikan mitigasi bencana di sekolah; dan adanya pengaruh dari lingkungan kerja. Sedangkan faktor penghambat yang ditemui dalam pelaksanaan pendidikan mitigasi bencana pada keluarga di Kepuharjo yakni adanya trauma dan tingkat pemahaman yang dimiliki oleh anak; ketidakstabilan sikap yang dimiliki oleh anak; kondisi yang dimiliki anggota keluarga; dan minimnya materi mitigasi bencana yang diberikan orang tua.

Dampak yang dirasakan oleh masyarakat dengan adanya penerapan pendidikan mitigasi bencana pada keluarga di Desa Kepuharjo antara lain terdapat dampak positif dan dampak negatif. Dampak positif penerapan pendidikan mitigasi bencana pada keluarga, antara lain meningkatkan kewaspadaan masyarakat dalam menghadapi erupsi Gunung Merapi; meningkatkan pemahaman mitigasi bencana yang dimiliki masyarakat; meningkatkan solidaritas sosial yang dimiliki masyarakat; dan meningkatkan kesadaran untuk menjaga kelestarian alam. Sedangkan dampak negatif diterapkannya pendidikan mitigasi bencana pada keluarga di Desa Kepuharjo yakni adanya penyalahgunaan pengetahuan mitigasi yang dimiliki anak.

\section{Ucapan Terima Kasih}

Terima kasih kepada semua pihak yang mendukung penulisan artikel ini dan kepada tim redaksi Jurnal Dimensia Pendidikan Sosiologi UNY yang telah menerbitkan karya ini.

\section{Daftra Pustaka}

Akbar, Wishnugroho. 2018. Merapi Kembali Meletus, Pengungsi Bertahan di Posko. Tersedia di : https://www.cnnindonesia.com/n asional/20180524071 708-20300845/merapi-kem bali-meletuspengungsi-bert ahan-di-posko diakses pada 10 November 2019 pukul 06.36 WIB

Astutik, Dwi. 2017. "Telah Kritis Gagasan Sosialisasi Mead: Self, Mind, Society". Vol. 1 No. 01

Dwiningrum, Siti Irene Astuti dan Sudaryono. 2010. "Peran Sekolah dalam Pembeajaran Mitigasi Bencana". Volume 1: 11-12

Karmin. 2015. Kontruksi Realitas Sosial sebagai Gerakan Pemikiran (Sebuah Telaah Teoritis Terhadap Kontruksi Realitas Peter L. Berger). Jakarta: BPPKI Jakarta

Khairudin. 2008. Sosiologi Keluarga. Yogyakarta : Liberty Yogyakarta

Kusumasari, Bevaola. 2014. Manajemen Bencana dan Kapabilitas Pemerintah Lokal. Yogyakarta : Penerbit Gava Media

Ma'arif, Syamsul dan Dyah R.H. 2015. Strategi Menuju Masyarakat Tangguh Bencana Dalam Perspektif Sosial. Yogyakarta : Gadjah Mada University Press

Miles, M.B., Huberman., \& Saldana, J. 2014. Qualitative Data Analysis: A Methods Sourcebook. Arizona State University. Third Edition

Murdiastomo, Agus. 2011. Belajar dari Bantul : Integrasi PRB dalam Mata Pelajaran. Prosiding Semiloka Nasional "Urgensi Pendidikan Mitigasi Bencana". Yogyakarta. 11-12 Mei 2011

Noor, Djauhari. 2014. Pengantar Mitigasi Bencana Geologi. Yogyakarta : Deepublish

Nurjanah, dkk. 2013. Manajemen 
Bencana. Alfabeta

Pingit. 2019. Gunung Merapi Erupsi Lagi, Sejarah Letusan 3000 Tahun.

https://katadata.co.

d/berita/2019/08/14/gunung-

merapi-erupsi-lagi-sejarah-

letusan-3000-tahun diakses pada

19 Oktober 2019 pukul 11.00 WIB

Sefrina, Fauziah. 2016. Hubungan

Dukungan Keluarga dan

Keberfungsian Sosial pada

Pasien Skizofrenia Rawat Jalan.

Vol.04 No.02 Agustus 2016

Septikasari, dkk. 2018. Strategi Integrasi

Pendidikan Kebencanaan dalam

Optimalisasi Ketahanan

Masyarakat Menghadapi

Bencana Erupsi Gunung Merapi.

Yogyakarta : Universitas Gajah

Mada. Vol.24,No.1,47-59

Syarif, Jamal. Sosialisasi NilaiNilai Kultural dalam Keluarga Studi Perbandingan Sosial-Budaya Bangsa-Bangsa. Banjarmasin:

Tarbiyah IAIN Antasari 